\title{
THE SPECIFICITY OF NATURAL HABITATS OF MENYANTHES TRIFOLIATA L. IN PEAT BOGS OF THE CENTRAL PART OF EASTERN POLAND
}

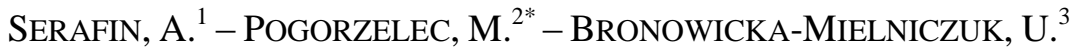 \\ ${ }^{I}$ Department of General Ecology, University of Life Sciences in Lublin \\ Leszczyńskiego 58, 20-068 Lublin, Poland \\ ${ }^{2}$ Department of Hydrobiology, University of Life Sciences in Lublin \\ Dobrzańskiego 37, 20-262 Lublin, Poland \\ (phone: +48-81-461-0061 ext.304) \\ ${ }^{3}$ Department of Applied Mathematics and Computer Science, \\ University of Life Sciences in Lublin \\ Gtęboka 28, 20-612 Lublin, Poland \\ *Corresponding author \\ e-mail: magdalena.pogorzelec@up.lublin.pl \\ (Received $14^{\text {th }}$ Jun 2016; accepted $8^{\text {th }}$ Mar 2017)
}

\begin{abstract}
Menyanthes trifoliata L. is one of plant species with medicinal properties which are harvested in Poland only from natural stands and at the same time it is a partially protected species. Due to the potential need to grow organic crops of $M$. trifoliata, an attempt was made to determine the optimal conditions for its growth in natural habitats with no human pressure. The aim of the present study was to determine habitat conditions in natural stands of the species $M$. trifoliata based on an analysis of selected physico-chemical groundwater factors. The obtained results showed that the following factors might have been important for the numbers and thus the condition of the populations of the species studied: $\mathrm{N}_{\text {total }}$, $\mathrm{P}_{\text {total }}$, electrolytic conductivity, and $\mathrm{pH}$. To grow organic crops of M. trifoliata, appropriate soil conditions should be created, under which the ranges of concentration values of the determined limiting factors should be within the limits of their mean values found at the sites with the most numerous populations of this species: $\mathrm{N}_{\text {total }}$ from 4.16 to $27.4 \mathrm{mg} \cdot \mathrm{dm}^{-3} ; \mathrm{P}_{\text {total }}$ from 0.93 to $0.14 \mathrm{mg} \cdot \mathrm{dm}^{-3}$; CON from 70.4 to 112 $\mu \mathrm{S} \cdot \mathrm{cm}^{-1}$; and $\mathrm{pH}$ from 5.23 to 5.55 .
\end{abstract}

Keywords: bogbean, peat bog, phytotherapy, groundwater, Lęczna-Wtodawa Lakeland

\section{Introduction}

The latest biochemical research on phytotherapy confirms that natural active substances exhibit multifaceted effects, have no aggressive impact on the patient's body, and provide a full range of readily available vitamins, enzymes, biocatalysts, immunostimulants as well as micro- and macronutrients (Brinkmann et al., 2007; Buettner et al., 2009; Oliveira et al., 2012; Senderski, 2015). Due to significantly lower production costs and the absence of the need to patent this type of products, the use of herbs is additionally becoming more widespread across the world (Bayles, 2007; Buettner et al., 2009; Mahmood and Malik, 2012).

The efficacy of phytotherapeutic treatments is primarily associated with the quality of herbal materials which should meet increasingly higher requirements, in particular those relating to the content of biologically active substances and the amount of contaminants of various kinds (Ruzik-Kuklińska, 2010; Seidler-Łożykowska et al., 2015). 
Where there is no anthropogenic pressure, herbal plants, evolutionarily adapted to their natural habitats, are characterized by a natural content and proportion of biologically active components. Therefore, medicinal products manufactured from such plants according to Good Manufacturing Practice (GMP) optimally fulfil the definition of a natural plant medicine that complies with the WHO recommendations (Borkowski, 1994; Drozd, 2012).

Hence, harvesting plants from natural habitats with a limited impact of human activity or from organic crops grown under semi-natural conditions is a major alternative for securing high-quality herbal raw materials.

If an herbal raw material is harvested from natural stands, there are certain limitations and restrictions associated with terrain obstacles, applicable legislation in the case of nature conservation areas, and a relatively small amount of raw material thus obtained. Organic crops in the case of which the natural values of the physico-chemical factors of the habitat of a particular species are maintained present an attractive alternative in this respect, confirmed by scientific research, especially relative to conventional crops. The evidence of this can be the significantly higher contents of many biologically active substances, e.g. quercetin, kaempferol, myricetin, and luteolin as well as the following phenolic acids: gallic, chlorogenic, caffeic, ferulic, and sinapic, in numerous herbal plants (e.g. Melissa officinalis L., Rosmarinus officinalis L., Mentha arvenis L., Salvia officinalis L.) grown under semi-natural conditions relative to conventional crops (Kazimierczak et al., 2012). In many cases, a similar relationship applies to the dry matter content in herbal raw materials obtained from organic crops (Seidler-Łożykowska et al., 2008; Kazimierczak et al., 2011; Kazimierczak et al., 2012).

Conventional galenic medicines, frequently with a several-century-long tradition of effective therapeutic use, compounded from herbal ingredients that have been collected from natural habitats often have an increased content and naturally specific composition of active substances and hence their multifaceted therapeutic functions depend on obtaining herbal raw material from wild stands or from organic crops grown under semi-natural conditions.

Bogbean (Menyanthes trifoliata L.) is one of plant species with medicinal properties which are harvested in Poland only from natural stands. This is a perennial plant with a thick cylindrical rhizome, with nodes and internodes, which belongs to the family Menyanthaceae (Hewett, 1964; Piękoś-Mirkowa and Mirek, 2006; Balcer-Żbikowska, 2012).

M. trifoliata is native to the northern hemisphere and the temperate circumpolar zone of Europe, Asia, and North America, growing on the edges of marshes, transition mires and raised bogs as well as in acidic wet sedge meadows, marshy meadows, and drainage ditches (Hewett, 1964; Balcer-Żbikowska, 2012).

Leaves of this species gathered during flowering of plants are used as herbal material; they contain iridoid and secoiridoid glycosides, flavonoids, tannins, phenolic acids (ferulic, chlorogenic, caffeic, benzoic, salicylic), coumarins, triterpenes, and small amounts of alkaloids (Kohlmünzer, 2000; Matławska, 2008). Bogbean leaf infusions are used internally and they cause increased gastric juice secretion, regulate digestive processes through cholagogic activity, and have toning-up, anti-inflammatory, antirheumatic, antimigraine, purgative, and antiscorbutic properties (LewkowiczMosiej, 2003; Balcer-Żbikowska, 2012; Senderski, 2015).

Bogbean is a perennial plant, a hydrophyte belonging to the Holoarctic, circumboreal element, which prefers cool, wet, acidic, oligotrophic sites with moderate light conditions on organogenic soils associated with raised bogs or transition mires. As a 
result of the changes in water relations in many areas (drainage, irrigation), both the numbers of stands and the number of individuals of this species in these stands are gradually decreasing (Zarzycki et al. 2002; Balcer-Żbikowska, 2012). On account of this, the species is partially protected in Poland (the Regulation of the Minister of Environment of 20 January 2012).

Due to the potential need to grow organic crops of $M$. trifoliata, an attempt was made to determine the optimal conditions for its growth in natural stands with no human pressure. The aim of the study presented in this paper was to determine habitat conditions based on an analysis of selected abiotic environmental factors in natural stands of the M. trifoliata population in the Polesie Podlaskie region.

\section{Procedures}

This study was conducted in the peat bogs of the Lęczna-Włodawa Lakeland located in Polesie Podlaskie (Poland). During the first stage of the study, six sites were selected where the $M$. trifoliata population occurred and which were located within nature conservation areas or in their vicinity (Fig. 1). Study areas of $100 \mathrm{~m}^{2}(10 \mathrm{~m} \times 10 \mathrm{~m})$ each were designated in the following lake-bog complexes: Lake Bikcze (B), Lake Karaśne (K), Lake Długie (D), Lake Moszne (M), and the mid-forest bogs Blizionki (BZ) and Dekowina (DK). The study sites varied in terms of the abundance of the $M$. trifoliata population, as measured by the percentage contribution of its individuals to the phytocoenosis.

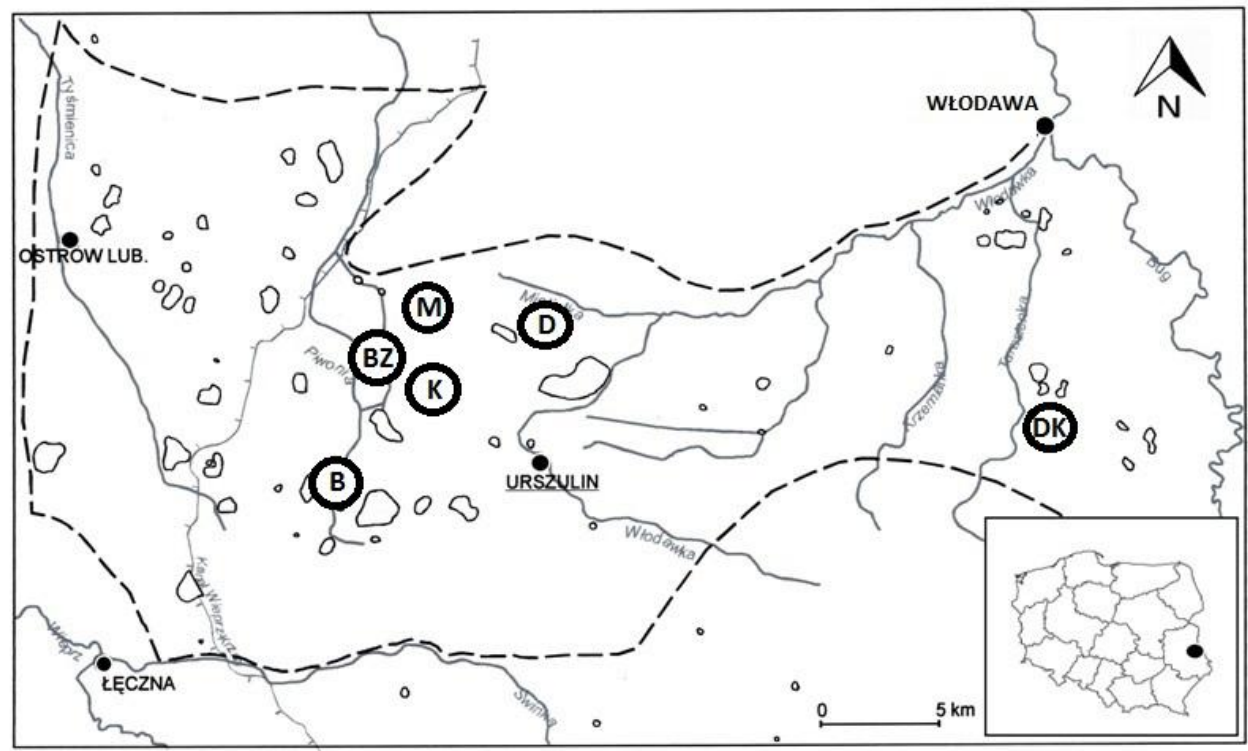

Figure 1. Location of the study sites in the Polesie Podlaskie region (B - Bikcze, M - Moszne, K-Karaśne, D - Dtugie, BZ - Blizionki, DK-Dekowina)

The coordinates were determined for the central part of the stand where the

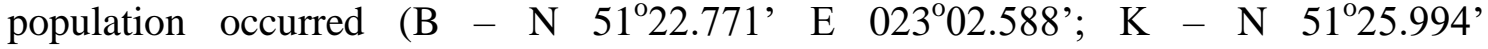

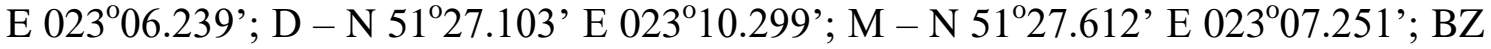
- N 51 ${ }^{\circ} 25.649^{\prime}$ E $023^{\circ} 04.176^{\prime}$; DK - N 51 ${ }^{\circ} 26.689^{\prime}$ E $023^{\circ} 31.368^{\prime}$ ) and soil piezometers (a $1 \mathrm{~m}$ long perforated PVC pipe with a diameter of $10 \mathrm{~cm}$ buried in the soil) were installed there to collect bog water samples. 
Each year over the period 2011-2013, laboratory analyses of piezometric water sampled were carried out seven times during the following seasons: spring, summer, and autumn. The tests were made at the Central Agro-Ecological Laboratory of the University of Life Sciences in Lublin using certified methods; testing included 14 physico-chemical parameters of the bog water: electrolytic conductivity $(\mathrm{CON}), \mathrm{pH}$, the amount of dissolved organic carbon (DOC), the content of nitrogen fractions: total nitrogen $\left(\mathrm{N}_{\text {total }}\right)$, ammonium nitrogen $\left(\mathrm{N}-\mathrm{NH}_{4}\right)$, nitrates $\left(\mathrm{N}-\mathrm{NO}_{3}\right)$, nitrites $\left(\mathrm{N}_{-} \mathrm{NO}_{2}\right)$, and of phosphorus fractions: total phosphorus $\left(\mathrm{P}_{\text {total }}\right)$, phosphates $\left(\mathrm{P}-\mathrm{PO}_{4}\right)$, as well as the content of sulfates $\left(\mathrm{S}_{-} \mathrm{SO}_{4}\right)$ and major cations: potassium $(\mathrm{K})$, sodium $(\mathrm{Na})$, calcium $(\mathrm{Ca})$, and magnesium $(\mathrm{Mg})$.

Additionally, the study of the habitats was complemented by determining the species composition of the phytocoenoses at the study sites. The Jaccard similarity indices (Piernik, 2009) were also calculated for all phytocoenoses investigated.

The study results were statistically analyzed using direct ordination methods (RDA). Environmental variables were selected assuming a correlation factor of $> \pm 0.6$ between the variables as the rejection criterion (Zuur et al., 2007).

We decided to apply the square root transformation and standardization on $\mathrm{N}_{\text {Total }}$,

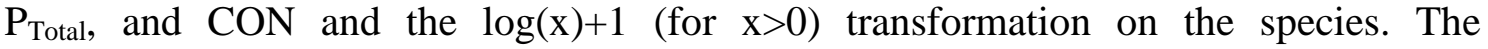
redundancy analysis results are visualized in a triplot ordination diagram. All three explanatory variables explain $68.05 \%$ of the total variation. The first two RDA axes explain $49.9 \%$ of the total variation in the species data. Due to the lack of normality of distribution and the heterogeneity of variance across the data sets of the parameters investigated, the nonparametric Kruskal-Wallis test was employed to compare the distributions of their values in the particular habitats. R 3.0.2 software ( $R$ Core Team 2016) was used for all statistical analyses and the vegan package 2.0-8 (Oksanen et al., 2016) for multivariate investigations.

\section{Results and discussion}

The peat bogs of the Łęczna-Włodawa Lakeland form a characteristic habitat associated with the variety of the hydrological network, a specific microclimate corresponding to tundra, and low pressure of human activity. In combination with the typological diversity of the bogs themselves, these facts determine the possibility of the occurrence of many plant species that are environmentally valuable and useful to humans. One of them is the species $M$. trifoliate, whose therapeutic efficacy has been confirmed by the tradition of its use and by pharmacological investigations (Hegi, 1926; Drobnik and Drobnik, 2007; Martz et al., 2009).

During the observations conducted over the period 2011-2013, it was found that the bogbean population numbers varied depending on the site. Numerous $M$. trioliata populations were found in the bog-lake complexes of the lakes Bikcze and Dhugie (B and D) as well as in the Dekowina bog (DK), where their percentage contribution to the phytocoenoses at these study sites was more than $15 \%$. At the other study sites, the percentage of $M$. trifolata in the phytocoenosis was much lower (from $1 \%$ at sites $\mathrm{K}$ and $\mathrm{BZ}$ to $2 \%$ at site $\mathrm{M}$ ).

In each case, the species composition of the phytocoenoses at the study sites was characterized by the occurrence of species such as Carex rostrata, Equisetum limosum, Betula pubescens and other herbal plants like Oxycoccus palustris and Comarum 
palustre. However, the species similarity index for these phytocoenoses rarely exceeded 0.5 , which suggests a high variation of the flora between the habitats studied (Table 1).

Table 1. Values of the Jacckard similarity index between study sites

(B-Bikcze, M-Moszne, K- Karaśne, D-Dlugie, BZ-Blizionki, DK-Dekowina)

\begin{tabular}{|c|c|c|c|c|c|c|c|c|c|}
\hline B-M & 0.38 & M-D & 0.54 & D-K & 0.54 & K-BZ & 0.38 & BZ-DK & 0.33 \\
\hline B-D & 0.51 & M-K & 0.52 & D-BZ & 0.41 & K-DK & 0.46 & & \\
\hline B-K & 0.56 & M-BZ & 0.31 & D-DK & 0.46 & & & & \\
\hline B-BZ & 0.34 & M-DK & 0.43 & & & & & & \\
\hline B-DK & 0.46 & & & & & & & & \\
\hline
\end{tabular}

In the case of $M$. trifoliata and many other medicinal plants, environmental variability deserves special attention among the factors affecting the content of bioactive substances and raw material content during plant growth. It is related to the effects of climatic factors (e.g. sunlight duration, temperature, day length, rainfall) and edaphic (soil and habitat) factors, i.e. fertility, $\mathrm{pH}$, water relations, soil structure, the amount of organic matter, or the content of different elements in the soil solution (Kazimierczak et al., 2010; Senderski, 2015).

Plants occurring in natural habitats with a low impact of anthropogenic pressure are evolutionarily adapted to the complex of environmental factors that undergo certain small, constant fluctuations in their intensity in specific climate zones. If their values oscillate within the limits of ecological tolerance, the physiological homeostasis mechanisms will allow the plant life strategy to be implemented effectively (Falińska, 2004).

The values of the physico-chemical habitat factors, which were investigated in groundwater during the period 2011-2013, were supposed to present a fuller picture of the habitat preferences of the species studied. Unfortunately, due to significant deviations of single results, the mean values of most of the factors (e.g. $\mathrm{N}_{\text {total }}, \mathrm{P}_{\text {total }}, \mathrm{S}$ $\mathrm{SO}_{4}, \mathrm{DOC}, \mathrm{CON}, \mathrm{Na}$, and $\mathrm{Ca}$ ) were sometimes outside the range of the normal distribution of observations, giving a slightly misleading notion of the intensity of a specific character (Table 2). The ranges of the values of some factors (i.e. $\mathrm{N}_{\text {total }}$, $\mathrm{P}_{\text {total }}$, $\mathrm{CON}$, and $\mathrm{pH}$ ) depending on the site sometimes varied, additionally displaying a broad amplitude of ecological tolerance of bogbean (Fig. 2).

Table 2. Values of the physico-chemical factors of piezometric water at all the study sites with preliminary statistical analysis

\begin{tabular}{ccccccc}
\hline FACTOR & min & max & median & mean & SD & V\% \\
\hline $\mathbf{N}_{\text {Total }}$ & 0.05 & 182.8 & 7.14 & 22.56 & 35.48 & 157 \\
\hline $\mathbf{N}_{\mathbf{N H}}$ & 0.10 & 5.00 & 0.21 & 0.75 & 1.17 & 157 \\
\hline $\mathbf{N}-\mathbf{N O}_{\mathbf{3}}$ & 0.05 & 0.12 & 0.05 & 0.05 & 0.01 & 24 \\
\hline $\mathbf{N}_{\mathbf{N O}}$ & 0.10 & 0.68 & 0.10 & 0.15 & 0.13 & 89 \\
\hline $\mathbf{P}_{\text {Total }}$ & 0.04 & 1.78 & 0.34 & 0.42 & 0.40 & 96 \\
\hline $\mathbf{P - P O}_{\mathbf{4}}$ & 0.10 & 4.55 & 0.10 & 0.53 & 0.86 & 162 \\
\hline $\mathbf{S - S O _ { 4 }}$ & 0.10 & 40.19 & 0.27 & 2.15 & 6.70 & 311 \\
\hline $\mathbf{D O C}$ & 16.90 & 84.10 & 42.54 & 45.15 & 18.46 & 41 \\
\hline $\mathbf{C O N}$ & 32.60 & 381.30 & 105.10 & 129.04 & 85.06 & 66 \\
\hline $\mathbf{p H}$ & 4.62 & 6.50 & 5.50 & 5.61 & 0.45 & 8 \\
\hline $\mathbf{N a}$ & 3.30 & 249.60 & 6.70 & 18.53 & 43.92 & 237 \\
\hline $\mathbf{K}$ & 0.85 & 9.55 & 3.16 & 3.76 & 2.29 & 61 \\
\hline $\mathbf{C a}$ & 0.96 & 75.10 & 17.10 & 24.26 & 18.36 & 76 \\
\hline $\mathbf{M g}$ & 0.14 & 6.03 & 1.88 & 2.05 & 1.34 & 65 \\
\hline
\end{tabular}


Table 3. Mean values of the physico-chemical factors of groundwater at the sites representative of the occurrence of M. trifoliata over the period 2011-2013

\begin{tabular}{ccccccccc}
\hline Study site & \multicolumn{4}{c}{ B (Bikcze) } & \multicolumn{5}{c}{ D (Długie) } \\
\hline FACTOR & mean & median & SD & V\% & mean & median & SD & V\% \\
\hline $\mathbf{N}_{\text {Total }}$ & 27.46 & 18.62 & 26.93 & 98 & 4.16 & 3.39 & 5.09 & 122 \\
\hline $\mathbf{N}_{\mathbf{N H}}$ & 0.76 & 0.22 & 1.02 & 134 & 0.20 & 0.20 & 0.10 & 51 \\
\hline $\mathbf{N}_{\mathbf{N} \mathbf{O}_{3}}$ & 0.05 & 0.05 & 0.01 & 14 & 0.05 & 0.05 & 0.01 & 14 \\
\hline $\mathbf{N}_{\mathbf{N O}} \mathbf{2}_{\mathbf{2}}$ & 0.10 & 0.10 & 0.00 & 4 & 0.16 & 0.10 & 0.17 & 93 \\
\hline $\mathbf{P}_{\text {Total }}$ & 0.93 & 0.65 & 0.52 & 56 & 0.14 & 0.06 & 0.11 & 82 \\
\hline $\mathbf{P - P O}_{\mathbf{4}}$ & 1.40 & 0.74 & 1.56 & 112 & 0.17 & 0.10 & 0.17 & 101 \\
\hline $\mathbf{S - S O _ { 2 }}$ & 2.22 & 0.18 & 5.05 & 227 & 0.85 & 0.18 & 1.67 & 196 \\
\hline $\mathbf{D O C}$ & 50.43 & 54.23 & 17.22 & 34 & 28.49 & 25.95 & 6.59 & 23 \\
\hline $\mathbf{p H}$ & 5.23 & 5.30 & 0.28 & 5 & 5.55 & 5.70 & 0.24 & 4 \\
\hline $\mathbf{C O N}$ & 70.46 & 72.20 & 27.43 & 39 & 112.41 & 107.60 & 8.48 & 8 \\
\hline $\mathbf{N a}$ & 13.82 & 11.00 & 12.33 & 89 & 11.17 & 5.00 & 13.81 & 124 \\
\hline $\mathbf{K}$ & 5.64 & 5.33 & 2.54 & 45 & 2.27 & 1.60 & 2.08 & 92 \\
\hline $\mathbf{C a}$ & 7.14 & 5.18 & 5.82 & 82 & 20.42 & 17.00 & 6.88 & 34 \\
\hline $\mathbf{M g}$ & 1.68 & 0.77 & 1.61 & 96 & 1.73 & 1.44 & 0.99 & 57 \\
\hline
\end{tabular}

Table 4. Values of Kruskal-Wallis test statistics, $p$-values, and multiple comparison results for the factor values observed at the particular sites (column I-type of the factor studied; column II - values derived from the test statistics; column III - p-values; column IV - multiple comparison results; the sites for which significant differences were found at a significance level of 0.05 are marked in color; $\mathrm{Na}, \mathrm{K}, \mathrm{Mg}, \mathrm{S}_{-} \mathrm{SO}_{4}, \mathrm{~N}-\mathrm{NO}_{2}, \mathrm{~N}-\mathrm{NO}_{3}-$ no significant statistical differences)

\begin{tabular}{|c|c|c|c|c|c|c|c|c|c|c|c|c|c|}
\hline \multirow[b]{2}{*}{ FACTOR } & \multirow{2}{*}{$\begin{array}{l}\text { Kruskal- } \\
\text { Wallis } \chi^{2} \\
\text { statistics }\end{array}$} & \multirow[b]{2}{*}{ p-value } & \multicolumn{11}{|c|}{ Multiple comparison test after Kruskal-Wallis } \\
\hline & & & & คे & 光 & á & $\sum_{\infty}^{\infty}$ & 令光光 & $\sum_{\substack{1 \\
N}}$ & 光 & பี & 商 & 光光之党 \\
\hline I & II & III & & & & & & IV & & & & & \\
\hline $\mathbf{N}$ & 21.622 & 0.0006178 & & & & & & & & & & & \\
\hline CON & 28.913 & $2.412 \cdot 10^{-5}$ & & & & & & & & & & & \\
\hline $\mathbf{P}$ & 29.73 & $1.667 \cdot 10^{-5}$ & & & & & & & & & & & \\
\hline pH & 25.524 & 0.0001104 & & & & & & & & & & & \\
\hline N-NH 4 & 17.513 & 0.003624 & & & & & & & & & & & \\
\hline $\mathrm{P}_{-} \mathrm{PO}_{4}$ & 27.917 & $3.778 \cdot 10^{-5}$ & & & & & & & & & & & \\
\hline DOC & 15.271 & 0.009267 & & & & & & & & & & & \\
\hline $\mathbf{C a}$ & 17.642 & 0.003431 & & & & & & & & & & & \\
\hline
\end{tabular}

Similar value ranges at all the sites investigated were only found for $\mathrm{N}-\mathrm{NO}_{3}$ and $\mathrm{Na}$ ions. At study site $\mathrm{B}$, where $M$. trifoliata occurred in greatest numbers, the parameters $\mathrm{N}_{\text {total }}, \mathrm{N}-\mathrm{NH}_{4}$, and $\mathrm{S}-\mathrm{SO}_{4}$ had much higher mean values compared to the other sites. However, they were lower than those for study site D, which was also characterized by a high proportion of the studied species in the phytocoenosis.

The study results also revealed that the concentrations of the tested phosphorus fractions and $\mathrm{K}$ ions were much higher at the study site located on Lake Bikcze relative to the other sites, whereas the $\mathrm{pH}, \mathrm{CON}$ as well as $\mathrm{Ca}$ and $\mathrm{Mg}$ ions had slightly lower 
values (see Table 2-4, Fig. 2). In the case of study site $\mathrm{D}$, only the content of $\mathrm{Na}, \mathrm{Mg}$, and $\mathrm{N}-\mathrm{NO}_{3}$ ions as well as the $\mathrm{pH}$ had similar values to those found for the site on Lake Bikcze (study site B). Correspondingly lower values of the concentrations in the tested water samples were also found for $\mathrm{N}_{\text {total }}, \mathrm{N}-\mathrm{NH}_{4}, \mathrm{P}_{\text {total }}, \mathrm{P}_{-} \mathrm{PO}_{4}, \mathrm{~S}-\mathrm{SO}_{2}, \mathrm{~K}$ ions, and DOC, while correspondingly higher values were found for $\mathrm{N}_{-} \mathrm{NO}_{2}, \mathrm{Ca}$ ions, and electrolytic conductivity (see Table 2-4, Fig. 2).
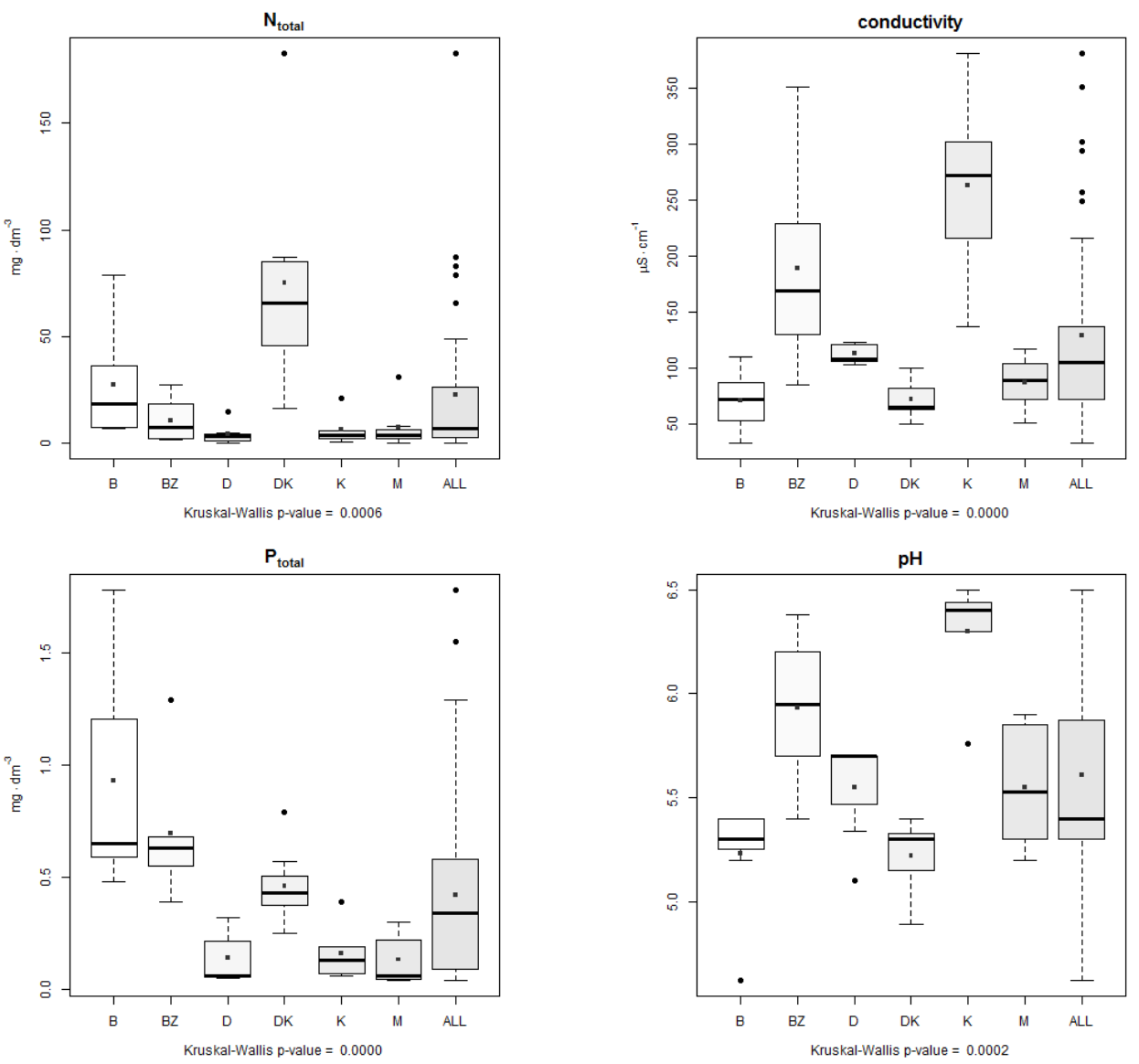

Figure 2. Distribution of values of the investigated chemical factors of piezometric groundwater at the study sites in 2011-2013 (The box-and-whisker plots show the distribution of observations. The bottom and top of the box indicate the first and the third quartiles, respectively. The horizontal line across the central region of the box represents the median. The mean value of the data is marked by a filled square. The whiskers are drawn to the most extreme observations that are located no more than 1.5 times the inter quartile range away from the box. Any observation not included between the whiskers is plotted as an outlier with an circle. When there are no outliers, the whiskers indicate the minimum and maximum values. The abbreviations of the selected study sites are used to label tick marks on the $x$-horizontal axis. The $x$ axis label provides the p-value derived from the Kruskal-Wallis test)

The high contribution of $M$. trifoliata to the phytocoenoses at study sites B and D allows us to consider the set of the values of the investigated physico-chemical factors of the habitat in this location to be appropriate for the growth and development of the species in question (see Table 2). 
A more in-depth statistical analysis gives more complete information on the habitat relationships with regard to the physico-chemical parameters. An analysis was conducted of the variation in the distribution of the values of the investigated factors at the particular sites based on the Kruskal-Wallis test and multiple comparisons at a significance level of 0.05 (Table 4).

Statistically significant differences were observed in the case of the distribution of the values of $\mathrm{N}_{\text {total }}, \mathrm{P}_{\text {total }}$, and electrolytic conductivity as well as of $\mathrm{pH}, \mathrm{N}-\mathrm{NH}_{4}, \mathrm{P}_{-} \mathrm{PO}_{4}$, DOC and $\mathrm{Ca}$, which means a variation in the distribution of the values of the factors at the particular study sites. If we assume a 5\% significance level for the results of the Kruskal-Wallis (K-W) tests, it is found that in the case of the parameters $\mathrm{N}-\mathrm{NO}_{2}, \mathrm{~N}-$ $\mathrm{NO}_{3}, \mathrm{~S}-\mathrm{SO}_{4}$ as well as $\mathrm{K}, \mathrm{Na}$, and $\mathrm{Mg}$ the distribution of each of the above-mentioned factors is invariant in relation to the sites studied. This may form the basis for the supposition that the above specified parameters do not affect the condition of the species studied - they are not limiting factors.

Statistically significant differences between the highest number of pairs of study sites $(\geq 3)$ related to the following parameters: $\mathrm{N}_{\text {total }}, \mathrm{P}_{\text {total }}$, electrolytic conductivity, and $\mathrm{pH}$ (Fig. 2); these are the factors that may affect the condition of the M. trifoliata population. In particular, the higher concentration of $\mathrm{N}_{\text {total }}$ and $\mathrm{P}_{\text {total }}$ as well as the reduced values of $\mathrm{pH}$ and $\mathrm{CON}$ can be considered to be a set of conditions promoting the proper functioning of individuals of the species studied, which is also translated into its numerous occurrence.

The data set was next subjected to DCA, as implemented in the decorana function, which showed a first-axis gradient length of 1.56 in standard deviation units. Therefore, RDA was undertaken by applying the rda function in the vegan package (Oksanen et al., 2016).

Due to the specificity of RDA analysis, the number of physico-chemical parameters was reduced. A high value of the correlation coefficient was adopted as the criterion of exclusion and the following three environmental variables were included in further analysis: $\mathrm{N}_{\text {total }}, \mathrm{P}_{\text {total }}$, and $\mathrm{CON}$.

The ordination analysis included 41 species (found at all the study sites), 6 study sites, and 3 selected environmental variables. We decided to apply the square root transformation and standardization on $\mathrm{N}_{\text {total }}, \mathrm{P}_{\text {total }}$, and $\mathrm{CON}$ and the $\log (\mathrm{x})+1($ for $\mathrm{x}>0$ ) transformation on the species. The redundancy analysis results are visualized in ordination diagrams (Fig. 3-4). All three explanatory variables explain 69.94\% of the total variation. The first two RDA axes explain $50.40 \%$ of the total variation in the species data $(\mathrm{RDA} 1=25.65 \%$, RDA2 $=24.75 \%)$. The results of the forward selection and permutation tests indicate that $\mathrm{N}_{\text {total }}$ is significantly related to the species data ( $\mathrm{p}<$ 0.05). There is also a significant CON effect $(\mathrm{p}<0.05)$ and $\mathrm{P}_{\text {total }}$ effect $(\mathrm{p}<0.1)$. We can also clearly observe three groups: group 1 (sites: M, D), group 2 (sites: B, K, BZ), group 3 (site DK) - Fig. 3.

The distances between the sites approximate Euclidean distances. Thus, the sites ordinated closer together can be expected to have a similar species composition and similar variable values. The triplot (Fig. 4) indicates a small positive correlation between $\mathrm{N}_{\text {total }}$ and $\mathrm{P}_{\text {total }}$ and a similar magnitude, but a negative correlation between $\mathrm{N}_{\text {total }}$ and $\mathrm{CON}$. 


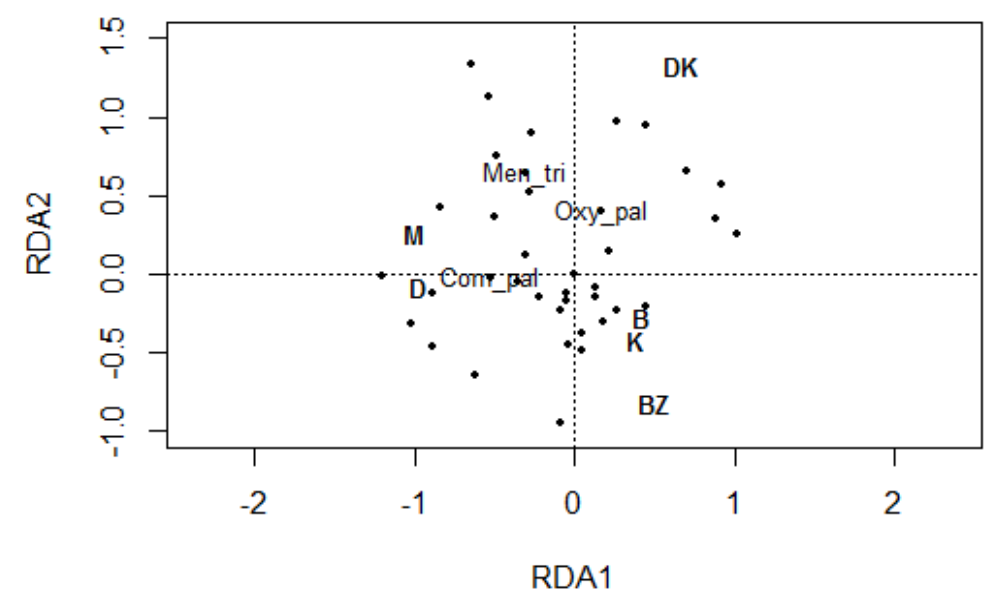

Figure 3. Biplot of the RDA with fitted site scores and species (herbal plants detailed) as labels, scaling $=1$

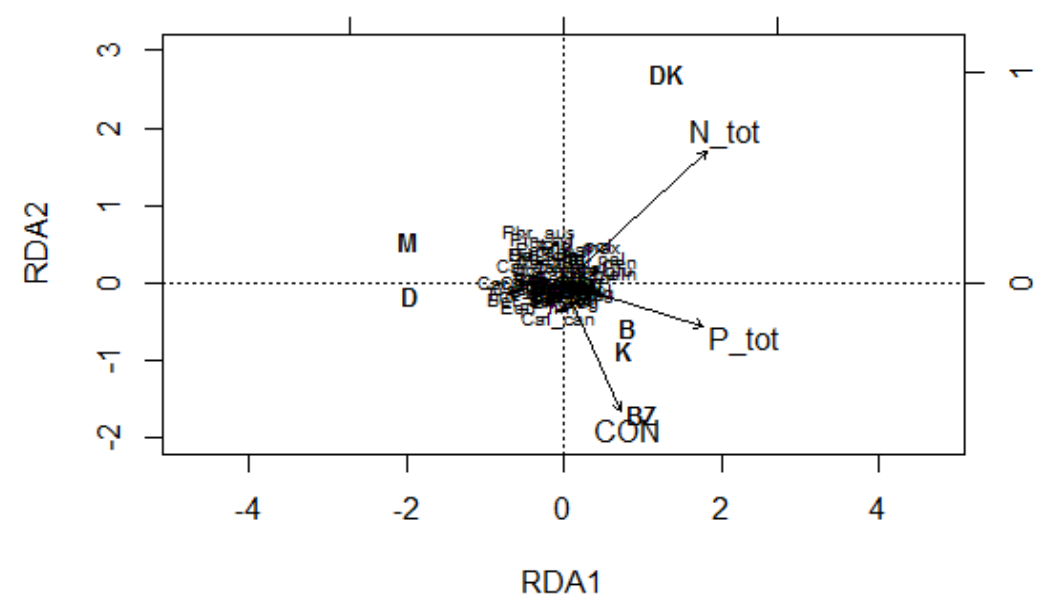

Figure 4. Triplot of the RDA with fitted site scores, species and environmental variables as arrows, scaling $=2$

\section{Conclusions}

1. Menyanthes trifoliata is a species characterized by a wide range of ecological tolerance with respect to most abiotic environmental factors corresponding to stands evolutionarily preferred by this species.

2. Among the 14 physico-chemical soil factors investigated, the following might have been the limiting factors: $\mathrm{N}_{\text {total }}, \mathrm{P}_{\text {total }}$, electrolytic conductivity, and $\mathrm{pH}$.

3. The high contribution of individuals of the studied species to the phytocoenoses at the study sites on the lakes Bikcze and Długie allows us to consider the set of the values of the physico-chemical factors of the habitat in this location to be appropriate for the proper growth and development of the population.

4. To grow organic crops of $M$. trifoliata, appropriate soil conditions should be created, under which the ranges of concentration values of the determined limiting factors should be within the limits of their mean values found at the sites with the most numerous populations of this species: $\mathrm{N}_{\text {total }}$ from 4.16 to $27.4 \mathrm{mg} \cdot \mathrm{dm}^{-3} ; \mathrm{P}_{\text {total }}$ from 0.93 to $0.14 \mathrm{mg} \cdot \mathrm{dm}^{-3}$; CON from 70.4 to $112 \mu \mathrm{S} \cdot \mathrm{cm}^{-1}$; and $\mathrm{pH}$ from 5.23 to 5.55. 


\section{REFERENCES}

[1] Balcer-Żbikowska, B. (2012): Resources of valuable medicinal plants of Włoszczowa district. Part 3 - bogbean Menyanthes trifoliata L. - Annales Academiae Medicae Silesiensis 66(6): 7-12.

[2] Bayles, B. P. (2007): Herbal and other complementary medicine use by Texas midwives. - J. Midwifery Womens Health 52(5): 473-478.

[3] Borkowski, B. (1994): Rośliny lecznicze w fitoterapii. - Instytut Roślin i Przetworów Zielarskich, Poznań.

[4] Brinkmann, H., Wibmeyer, K., Gehrmann, B. (2007): Fitoterapia - racjonalne porady i zalecenia. - Medpharm, Wrocław.

[5] Buettner, C., Mukamal, K. J., Gardiner, P., Davis, R. B., Phillips, R. S., Mittleman, M. A. (2009): Herbal supplement use and blood lead levels of United States adults. - Journal of General Internal Medicine 24(11): 1175-1182.

[6] Drobnik J., Drobnik E. (2007): Uwagi o nazewnictwie i dawnym zastosowaniu bobrka trójlistkowego (Menyanthes trifoliata L.). - Farmacja Polska 63: 75-78.

[7] Drozd, J. (2012): Wczoraj i dziś ziołolecznictwa. - Przegląd Medyczny Uniwersytetu Rzeszowskiego i Narodowego Instytutu Leków w Warszawie. Rzeszów. T2: 245-251.

[8] Falińska, K. (2004): Ekologia roślin. - Wydawnictwo Naukowe PWN, Warszawa.

[9] Hegi, G. (1926): Illustrierte Flora von Mittel - Europa. - Band VI Teil 3, München 156158.

[10] Hewett, D. G. (1964): Biological flora of the British Isles: Menyanthes trifoliata L. Journal of Ecology 52: 723 - 735.

[11] Kazimierczak, R., Hallmann, E., Ardasińska, B., Łoś, B., Rembiałkowska, E. (2012): The impact of organic and conventional crop production systems on phenolic compounds content in medicinal plants. - Journal of Research and Applications in Agricultural Engineering 57(3): 198-203.

[12] Kazimierczak, R., Hallmann, E., Kazimierczyk, M., Rembiałkowska, E. (2010): Antioxidants content in chosen spice plants from organic and conventional cultivation. Journal of Research and Applications in Agricultural Engineering 55 (3): 164-170.

[13] Kazimierczak, R., Hallmann, E., Sokołowska, O., Rembiałkowska, E. (2011): Bioactive substances content in selected species of medicinal plants from organic and conventional production. - Journal of Research and Applications in Agricultural Engineering 56 (3): 200-205.

[14] Kohlmünzer, S. (2000): Farmakognozja. - Wyd. PZWL. Warszawa: 178-179.

[15] Lewkowicz-Mosiej, T. (2003): Leksykon Roślin Leczniczych. - Wyd. Świat Książki, Warszawa.

[16] Mahmood, A., Malik, R. N. (2012): Indigenous knowledge of medicinal plants from Leepa valley, Azad Jammu and Kashmir, - Pakistan Journal of Ethnopharmacology 143(1): 338-346.

[17] Matławska, I. (2008): Farmakognozja. - Wydawnictwo Naukowe Uniwersytetu Medycznego im. Karola Marcinkowskiego w Poznaniu, Poznań: 134-135.

[18] Martz, F., Turunen, M., Julkunen-Tiitto, R., Lakkala, K., Sutinen, M-L. (2009): Effect of the temperature and the exclusion of UVB radiation on the phenolics and iridoids in Menyanthes trifoliata L. leaves in the subarctic. - Environmental Pollution 157: 34713478 .

[19] Oksanen, J.F., Blanchet, G., Kindt, R., Legendre, P., Minchin, P. R., O’Hara, R. B., Simpson, G. L., Solymos, P., Henry, M., Stevens, H., Wagner, H. (2016): Vegan: Community Ecology Package. R package version 2.4-1. http://CRAN.R-project.org/package=vegan.

[20] Oliveira, S.G.D., De Moura, F.R.R., Demarco, F.F., Da Silva Nascente, P., Del Pino, F.A.B., Lund, R.G. (2012): An ethnomedicinal survey on phytotherapy with professionals 
and patients from Basic Care Units in the Brazilian Unified Health System.- Journal of Ethnopharmacology 140(2): 428-437.

[21] Piernik, A. (2009): Metody numeryczne w ekologii. - Wyd. UMK, Toruń.

[22] Piękoś-Mirkowa, H., Mirek, Z. (2006): Rośliny chronione. - Oficyna Wydawnicza Multico, Warszawa: 115.

[23] R Core Team (2016). R: A language and environment for statistical computing. R. Foundation for Statistical Computing, Vienna, Austria. https://www.R-project.org/.

[24] Regulation of the Minister of Environment, 20 January 2012, on the protection of plant species (Low Gazette No. 14, pos. 81).

[25] Ruzik-Kuklińska, U. (2010): Rośliny lecznicze. - Wyd. Bellona, Warszawa.

[26] Seidler-Łożykowska, K., Gołcz, A., Wójcik, J. (2008): Yield and quality of sweet basil, savory, marjoram and thyme raw materials from organic cultivation on the composed manure. - Journal of Research and Applications in Agricultural Engineering 53 (4): 6366.

[27] Seidler-Łożykowska, K., Mordalski, R., Kucharski, W., Kędzia, E., Nowosad K., Bocianowski J. (2015): Effect of organic cultivation on yield and quality of lemon balm herb (Melissa officinalis L.). - Acta Scientiarum Polonorum Hortorum Cultus 14(5), 5567.

[28] Senderski, M.E. (2015): Prawie wszystko o ziołach i ziołolecznictwie. - Wydawnictwo własne. Podkowa Leśna.

[29] Zarzycki, K., Trzcińska-Tacik, H., Różański, W., Szeląg, Z., Wołek, J., Korzeniak, U. (2002): Ecological Indicator Values of Vascular Plants of Poland. - W. Szafer Institute of Botany, Polish Academy of Science, Kraków.

[30] Zuur, A.F., Ieno, E.N., Smith, G. M. (2007): Analysing Ecological Data. - Springer. 